\title{
Customer Perception about Private Label Brands in Salem
}

\section{K. Vidhya, Ganesan D.}

\begin{abstract}
The up scaling growth of economy not only bring changes to our environment but also have an impact on cost of living. So people become conscious about the price and quality of the product before they buy and many go for the offers and promotions made by E-Commerce sites which gives a tough competition to local retail stores also. Here the private label brands also start to capture the market share in each segment such that they are cost efficient and acts as alternative to national brands. This paper will explore the customer perception of PLB in Salem and focuses on factors such as price, quality, value, packing, store loyalty and identifies the benefits and difference between the PLB and national brands. The study was made in and aroundSalem (from April-May 2018), Tamilnaduwith the sample size of 100 with a well-structured questionnaire. Data werecollected and statistical tools like percentage analysis, weighted average analysed were used
\end{abstract}

Key words:Consumer Perception, brand choices, Value for money, Point of purchase

\section{INTRODUCTION}

India's GDP have growth rate of 7.2 per cent where the Indian retail industry contributes almost $10 \%$ of the country's GDP and the market is about to increase by $60 \%$ by 2020 .The retail market holds grocery, departmental stores, pharmacy, food and beverage and books, music and gifts, in each sector we have key players as a market leader. In this the food and grocery is expected to grow at a rate of 66 per cent and the apparel holds $40-45$ per cent growth in India.

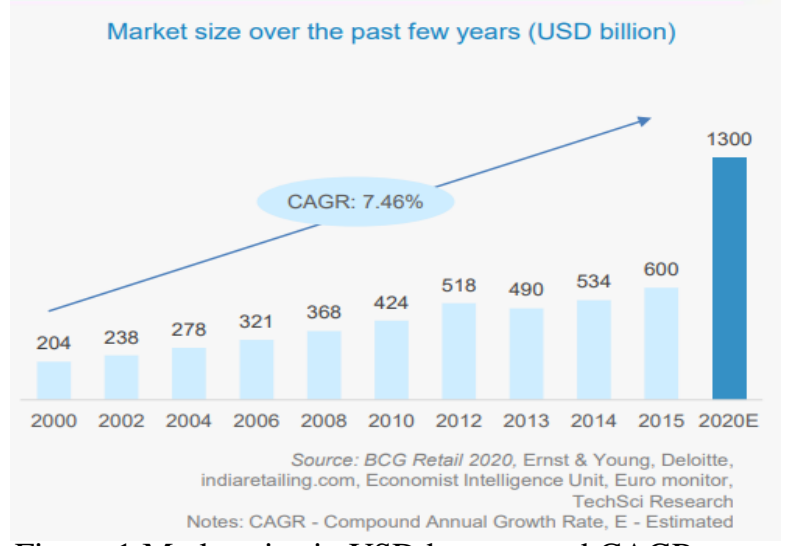

Figure: 1 Market size in USD by year and CAGR rate.

In general brand is used to identify the product in terms of name, logo, sounds, tagline, colour and symbols, this act as a communication between the product and consumer.

Revised Manuscript Received on December 16, 2019

Dr. D. Ganesan, Assistant Professor, Department of Management Studies, Sona College of Technology, Salem, Tamil Nadu, India.

Ms. K. Vidhya, Research Scholar, Department of Business Administration Under the guideline of DR. S. B. Inayath ahamed, Kalasalingam University.
Now the trend of Private label brands serves as alternate for people to switch from their loyal national brands. Currently in India the private label brands holds $7 \%$ of retail business and is expected to grow by 4 times in future. Thus the private label brands are products that are marketed \& sold only in their retail store, so called In-Store brands or Phantom brand. By this the private label brands gives the consumer an option with better price and quality.

\section{REVIEW OF LITERATURE:}

Scot Burton et.al., measures the attitude of people towards the private label brands with respect to price, quality, value and the brand loyalty the people hold and found some positive result that people feel private label brands as cost effective when compared to the branded ones.Sudhanshu Sekhar Kar et.al., brings out the insight of the private label product in the market and how the switching occurs from the branded and private label brand. The research concludes people are having an option for the branded at a cheaper price and the percentage of people moving to private label product starts increasing.Justin Beneke describes the consumer perception on the private label brands in south Africa with the factor like trust, packing, price and quality and finds that the people show a positive response towards the quality and show a poor response over the packing of the private label brands and considers the income as a major variable.Rajeev batra et.al., describes the success of the private label brands as how people consider the private label brands in comparative with the national brand such that how people differentiate and the factors that make the store brand more worth than the national brand.Zuraidah mohamed isa st.al., studied the decision making of the consumer, the private label and manufacturing brands and found price, quality and the space it is displayed make the consumer decision making process and is tilting towards the private brands in the market. Gianfranco Walsh el.al., describes perceived value of the private label brands by customers as high quality under low cost, this acts as a key by which customer are attracted by the private label brands.Siti Nurafifah Jaafar et.al.,measures the consumer perception of over the store brands in Malaysia that people see the store image, price, quality and the research focuses on food products. Here the price is the main objective of people who perceive the private label brands, the sales goes up by past experience and referral marketing by people.Jane Boyd Thomas et.al., explores the factors that influence the purchase of private label brand and national brand in apparel. Though the national brands are costly and fashion rich the private label brands offers the same trend of fashion wears at low cost and is made attractive.

N. Kakkos el.al., identifies the purchase intention of customer and brings out the facts as the people who are brand conscious and who seek social status move with national brands and the people

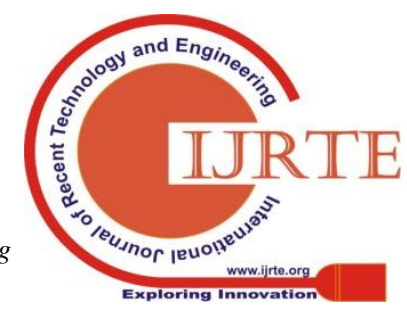




\section{Customer Perception about Private Label Brands in Salem}

familiar with store brands and price conscious move towards the private label brands.Carmen Abril el.al., describes the marketing mix of the private label brands and national brands in terms of the advertisements, price, distribution, display positions. The study shoes that the in-store communication and price effectiveness determines the sales of the private label brands.Lakshmi Nair describes how the private label brands change the consumer's perception mainly in the category of food and grocery even there are many loyal customers for the national brands and its quality.Chirag B. Rathod et.al., studies the psychological factors that influence the customer to buy private label apparels, among which the quality, value, price and the loyalty over the store acts positively that makes the customer to switch to the private label brands.Rajiv Vaidyanathan explores that how the retailers sell private label brands using the national brands as an ingredient by which the national brands are used to attract the customer and are tempted by the store brands price and quality.Paul C.S. Wu measure the effect of private label brands in drug store that how the store image, band image and service quality relatively increase the sale of private label brands and bought the fact that store value, service quality have a direct relation in decision making of consumer.

\section{OBJECTIVES OF THE STUDY}

- $\quad$ To find out the customer preference $\&$ perception about private brand labels.

- To identify the level of preference towards private label products.

- To examine various factors which influenced the buying behavior of the private label

- To analyze the private label product benefits as well as the difference between private brand and manufacture brand.

- To study the impact of price of product on buying behavior of the customers.

- To analyze the performance of private label brands with manufacturers brand.

\section{RATIONALE OF THE STUDY}

The present study related to the customer preference towards the private brands than manufacture brands and to identify the customer perception about the private brands at the retail store. The research mainly conducted to identify various factors influenced the buying behavior of the private label. This study mainly focusing on customer motivated factors to select the private brands and enables the researcher to find out the satisfaction level of the customer about private brands and also their expectation about private brands and intended to identify the pricing difference between private brands and manufacture brands.

The design of this research is descriptive and hypothetical in nature under which the researcher used questionnaire as an instrument to collect the primary data through the personal interview of survey method and secondary data for the literature review. Convenience sampling technique has been adopted by researcher for this study which is a nonprobability sampling method. The statements consist in the questionnaire prepared by the researcher. In order to collect the primary data, the researcher used convenience sampling method due to unknown population of this study. The study was conducted during the period of January 2018 to March 2018. The research holds a sample size of 100 from the various parts of Salem district. The collected data is processed by the way of coding, editing and tabulation and analyzed with the help of statistical tools such as percentage method, weighted average score analysis and correlation analysis.

\section{RESULTS AND DISCUSSION}

Table: 1 Demographic Factors.

\begin{tabular}{|c|c|c|c|}
\hline Factors & Category & Frequency & Percentage (\%) \\
\hline \multirow{4}{*}{ Age } & Below 25 & 32 & 32 \\
\hline & $26-35$ & 19 & 19 \\
\hline & $36-45$ & 43 & 43 \\
\hline & Above 45 & 6 & 6 \\
\hline \multirow[t]{2}{*}{ Gender } & Male & 58 & 58 \\
\hline & Female & 42 & 42 \\
\hline \multirow[t]{5}{*}{ Occupation } & Business & 10 & 10 \\
\hline & $\begin{array}{l}\text { Govt. } \\
\text { Employee }\end{array}$ & 28 & 28 \\
\hline & $\begin{array}{l}\text { Private } \\
\text { Employee }\end{array}$ & 33 & 33 \\
\hline & Student & 22 & 22 \\
\hline & Others & 7 & 7 \\
\hline \multirow[t]{5}{*}{$\begin{array}{l}\text { Family } \\
\text { Income }\end{array}$} & Below 20000 & 15 & 15 \\
\hline & $\begin{array}{l}20000 \quad- \\
30000\end{array}$ & 33 & 33 \\
\hline & $\begin{array}{l}30001=- \\
40000\end{array}$ & 14 & 14 \\
\hline & Above 40000 & 38 & 38 \\
\hline & Total & 100 & 100 \\
\hline
\end{tabular}

Table No.1 exhibits that the majority of people lie under the age of $36-45(43 \%)$ and followed by the age group of below $25(32 \%)$. Under the age group of $26-35(19 \%)$ and in the age group of above $40(6 \%)$. Among the 100 respondents there are about $58 \%$ male respondents and $42 \%$ female respondents. 
Regarding the occupation $10 \%$ respondents are business people, $28 \%$ people are Govt. employees and majority of people are private employees 33\%. Remaining 22\% are students and $7 \%$ belong to other occupation category. Under income range $38 \%$ of respondents fall have an income of above $40000,33 \%$ respondents have income of 20000$30000.15 \%$ of respondents hold an income of below 20000 and $14 \%$ have $30001-40000$.

Table: 2 Purchase frequency

\begin{tabular}{|l|l|l|l|}
\hline \multirow{4}{*}{$\begin{array}{l}\text { Purchase } \\
\text { frequency }\end{array}$} & Category & Frequency & Percentage \\
\cline { 2 - 4 } & Always & 6 & 6 \\
\cline { 2 - 4 } & Frequently & 36 & 36 \\
\cline { 2 - 4 } & At times & 38 & 38 \\
\cline { 2 - 4 } & Rarely & 20 & 20 \\
\cline { 2 - 4 } & Never & 0 & 100 \\
\cline { 2 - 4 } & Total & 100 & \\
\hline
\end{tabular}

Table No.2 demonstrates the purchase frequency of respondents as $38 \%$ of people have a neutral response, $36 \%$ of people frequently go for purchases, $20 \%$ of the people shop rarely and only $6 \%$ of respondents always go for shopping.

Table 3 : Purpose of purchase

\begin{tabular}{|l|l|l|l|}
\hline \multirow{3}{*}{$\begin{array}{l}\text { Purpose of } \\
\text { purchase }\end{array}$} & Category & Frequency & Percentage \\
\cline { 2 - 4 } & Personal use & 74 & 74 \\
\cline { 2 - 4 } & Business use & 18 & 18 \\
\cline { 2 - 4 } & Others & 8 & 8 \\
\hline & Total & 100 & 100 \\
\hline
\end{tabular}

From table : 3, it is clear that $74 \%$ of respondents are purchasing pvt.label brands for their personal use , $18 \%$ of them are using for business use and $8 \%$ of respondents are purchasing for other purposes

Table 4: Place of purchase (Pos)

\begin{tabular}{|l|l|l|l|}
\hline $\begin{array}{l}\text { Place of } \\
\text { purchase }\end{array}$ & Place (Pos) & Frequency & Percentage \\
\cline { 2 - 4 } & $\begin{array}{l}\text { Shopping } \\
\text { mall }\end{array}$ & 14 & 14 \\
\cline { 2 - 4 } & $\begin{array}{l}\text { Super } \\
\text { markets }\end{array}$ & 45 & 45 \\
\hline
\end{tabular}

\begin{tabular}{|l|l|l|l|}
\hline & $\begin{array}{l}\text { E- } \\
\text { Commerce } \\
\text { portals }\end{array}$ & 2 & 2 \\
\cline { 2 - 4 } & $\begin{array}{l}\text { Company } \\
\text { owned retail } \\
\text { outlets }\end{array}$ & 39 & 39 \\
\cline { 2 - 4 } & Others & 0 & 0 \\
\cline { 2 - 4 } & Total & 100 & 100 \\
\hline
\end{tabular}

The table No.4 brings the detail of places people opt for purchase, among 100 respondents $45 \%$ of people go for super markets, $39 \%$ move to company owned retail shops, $14 \%$ go for shopping malls and the rest purchase are from E-Commerce portals.

Table: 5 Frequency of purchase

\begin{tabular}{|l|l|l|l|}
\hline \multirow{4}{*}{$\begin{array}{l}\text { Frequency } \\
\text { of purchase }\end{array}$} & Place & Frequency & Percentage \\
\cline { 2 - 4 } & Weekly & 13 & 13 \\
\cline { 2 - 4 } & Monthly & 16 & 16 \\
\cline { 2 - 4 } & $\begin{array}{l}\text { Whenever } \\
\text { needed }\end{array}$ & 68 & 68 \\
\cline { 2 - 4 } & \begin{tabular}{l} 
In Offer period \\
\cline { 2 - 4 }
\end{tabular} & 2 & 2 \\
\cline { 2 - 4 } & Not purchased & 1 & 1 \\
\hline & yet & 100 & 100 \\
\cline { 2 - 4 } & Total & & \\
\hline
\end{tabular}

Table No.5 exhibits the time horizon of purchase by which $68 \%$ people go for purchase whenever needed, $16 \%$ of people purchase on monthly basis where only $2 \%$ of people shop on offer and the remaining $1 \%$ neglates shopping.

Table:6 Weighted average score analysis

\begin{tabular}{|l|l|l|l|}
\hline $\begin{array}{l}\text { Category of Private label } \\
\text { goods }\end{array}$ & Total score & Mean Score & Rank \\
\hline Consumer durables & 203 & 13.54 & V \\
\hline Food \& beverages & 452 & 30.14 & I \\
\hline Grocery & & & II \\
\hline Footwear & 331 & 22.07 & IV \\
\hline Apparels & & & III \\
\hline
\end{tabular}




\section{Customer Perception about Private Label Brands in Salem}

From above table it can be interpreted that based on their mean scores "Food \& beverages"are bought by the respondents most frequently, "Grocery" items are frequently bought, "Apparels " are moderate purchased, "Foot wares " are less frequently bought and "consumer durables" are never purchased by the respondents .

Table 7: Sources of information about private label brands

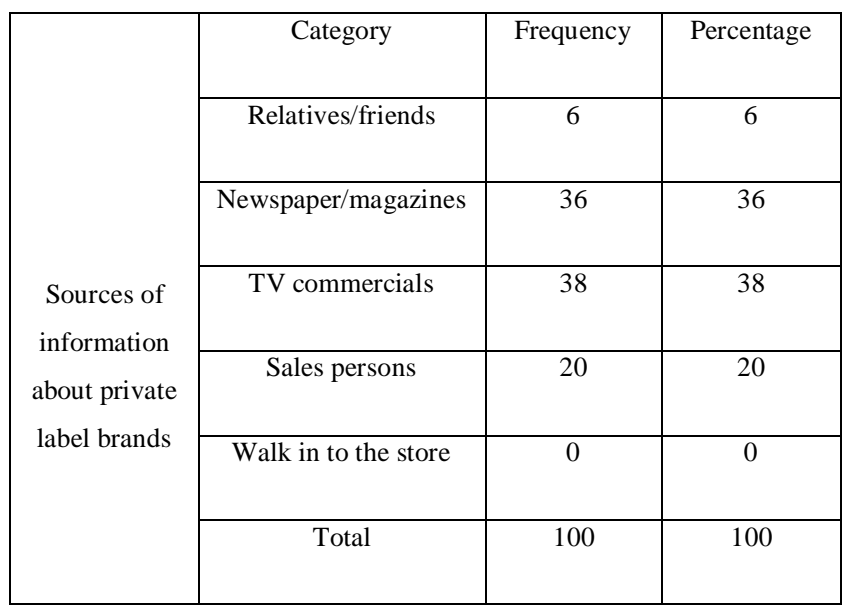

From table No.7 it is clear that studied as $38 \%$ of people come to know from TV Commercials, $36 \%$ of people are aware from newspaper and magazines, $20 \%$ of people knowPrivate label brands by sales person and remaining from relatives and friends.

Table 8: Opinion about Packagingof private label brands

\begin{tabular}{|l|l|l|l|}
\hline $\begin{array}{l}\text { Opinion } \\
\text { about } \\
\text { packaging }\end{array}$ & Opinion & Frequency & Percentage \\
\cline { 2 - 4 } & Attractive & 13 & 13 \\
\cline { 2 - 4 } & $\begin{array}{l}\text { Somewhat } \\
\text { attractive }\end{array}$ & 73 & 73 \\
\cline { 2 - 4 } & Unattractive & 14 & 14 \\
\cline { 2 - 4 } & Total & 100 & 100 \\
\hline
\end{tabular}

From Table : 8 , in terms of opinion about packaging of Private label brands, only $13 \%$ of respondents feel that the packing is attractive and $73 \%$ feel the packing as somewhat attractive and $14 \%$ feel that the packing is unattractive.

Table: 9Respondents Opinion about value of money of Private label brands

\begin{tabular}{|l|l|l|}
\hline $\begin{array}{l}\text { Opinion about } \\
\text { value for } \\
\text { money }\end{array}$ & Frequency & Percentage \\
\hline Excellent & 2 & 2 \\
\hline Good & 48 & 48 \\
\hline Mediocre & 45 & 45 \\
\hline Poor & 5 & 5 \\
\hline Very poor & 0 & 0 \\
\hline Total & 100 & 100 \\
\hline
\end{tabular}

From Table : 9 , It is revealed that in term of value for money $2 \%$ of respondents opined that Excellent where as $48 \%$ of respondents felt good , $45 \%$ of the respondents are opined as mediocre and rest of them are given opinion as poor label brands are value for money .

Table: 10 Respondents Opinion about performance of Private label brands

\begin{tabular}{|l|l|l|}
\hline $\begin{array}{l}\text { Opinion about } \\
\text { performance of } \\
\text { private label } \\
\text { brands }\end{array}$ & Frequency & Percentage \\
\hline Excellent & 12 & 12 \\
\hline Good & 47 & 47 \\
\hline Mediocre & 37 & 37 \\
\hline Poor & 4 & 4 \\
\hline Very poor & 0 & 0 \\
\hline Total & 100 & 100 \\
\hline
\end{tabular}

From Table : 10 , It is revealed that in terms of performance of private label brands $12 \%$ of respondents opined that Excellent where as $47 \%$ of respondents felt good, $37 \%$ of the respondents are opined as mediocre and rest of them are given opinion as poor label brands are value for money .

Table: 11 Coefficient of correlation analysis

\begin{tabular}{|l|l|l|l|l|}
\hline $\mathrm{X}$ & $\mathrm{Y}$ & $\mathrm{XY}$ & $\mathrm{X}^{2}$ & $\mathrm{Y}^{2}$ \\
\hline 32 & 6 & 192 & 1024 & 36 \\
\hline 19 & 36 & 684 & 361 & 1296 \\
\hline 43 & 38 & 1634 & 1849 & 1444 \\
\hline 6 & 20 & 120 & 36 & 400 \\
\hline & & 2630 & 3270 & 3176 \\
\hline
\end{tabular}

Co-efficient of correlation is used to find out the relationship between Ages and place of purchase (Pos) of private label brands

$$
\begin{aligned}
r & =\frac{\sum x y}{N \sigma x} * \sigma y \\
& =+0.816
\end{aligned}=\frac{\sum x}{\sqrt{\sum x} * \sqrt{\sum y 2}}
$$

There is an association between two variables existing relationship between age group \&place of purchase (Pos). Hence it is positively correlated.

\section{APPRAISING OUTCOMES}

- As more number of people are frequently purchasing private label branded goods, it is apparent that private label brands are achieving better patronage from consumers

- The private label goods are mostly purchased in Super markets and Company owned retail outlets because of convenience and more brand choices

- By using weighted average score analysis, it can be interpreted that "Food \& beverages" are bought by the respondents most frequently. Hence the food and beverages products manufactured by private label brands are giving fierce competition to national and international brands.

- Television commercials are the major Sources of providing information about private label brands. In particular, e-commerce private level brands are creating more awareness and providing information about their brands.

- Respondents are felt that, private label brands are 
providing better value for money

- Respondents are opined that the private label brands are as good as manufacturer brands in terms of their level of satisfaction

- There is a positive correlation found between age group of the respondents \& place

- of purchase (PoS)

\section{CONCLUSION AND MANAGERIAL IMPLICATIONS}

- In category of goods Apparels, Foot wares and consumer durables are not achieving better level; of purchase among respondents. Hence private label companies can provide better sales promotion to enhance the purchase of these products.

- In terms of (PoS), Shopping malls and e-commerce portals are not achieving better sales in private label goods. They can come with creative ways to lure consumers to enhance their point of purchase

- The packaging of private labelled goods can be improved to stand out in the competition with international and national brands

- More quantity offers and discounts can be leveraged to attract more people towards private label brands

- Even though, Private label brands are providing value for money and achieving satisfaction among the respondents, they should focus on to analyze the changing tastes and preferences of consumers. They should keep on putting efforts to predict and provide products which can live up to the expectations of the consumers in the VUCA world.

\section{REFERENCES}

1. Carmen Abril, Belén Rodriguez-Cánovas, (2016) "Marketing mix effects on private labels brand equity" European Journal of Management and Business Economics 25, 168-175.

2. Chirag B. Rathod, Nishithkumar H. Bhatt, (2013) "Role of psychological factors in purchase behaviour with reference to private label apparels" Asia-Pacific Journal of Management Research and Innovation, 9(2) 191-200.

3. Gianfranco Walsh, Vincent-Wayne Mitchell (2010) "Consumers' intention to buy

4. https://www.ibef.org/download/Retail-January-2017.pdf

5. https://www.ibef.org/industry/indian-retail-industry-analysispresentation

6. https://www.indiainfoline.com/article/news/indian-private-labelbrands-set-for-an-international-makeover-5939504879_1.htm

7. Justin Beneke, (2010)“'Consumer perceptions of private label brands within the retail grocery sector of South Africa" African Journal of Business Management 4(2), 203-220.

8. Lakshmi Nair, (2011) "Private labels brands in food \& grocery: the changing perceptions of consumers \& retailers in India- a study in the Pune region" International Refereed Research Journal 2(1),144

9. Mamta Ranga, (2017) "Private label brands retailers in India: Food and grocery sector"International Journal of Multidisciplinary Research and Development 4(5), 143-145.

10. Michael R. Hyman, Dennis A. Kopf, Dongdae Lee (2010) "Review of literature - Futureresearch suggestions: Private label brands: Benefits, success factors and future research" Journal of Brand Management 17(5), 368-389.

11. N. Kakkos, P., Trivellas, L., Sdrolias, (2015) "Identifying Drivers of Purchase Intention for Private Label Brands. Preliminary Evidence from Greek Consumers." Social and Behavioural Sciences 175, 522 528.

12. Paul C.S. Wu, Gary Yeong-Yuh Yeh, Chieh-Ru Hsiao, (2011) “The effect of store image and service quality on brand image and purchase intention for private label brands" Australasian Marketing Journal 19, 30-39.

13. private label brands revisited" Journal of General Management 35(3), $3-24$
14. Rajeev batra, Indrajit Sinha, (2000) "Consumer-Level factor moderating the success of private label brands" Journal of Retailing, Volume 76(2), 175-191.

15. Rajiv Vaidyanathan, Praveen Aggarwal, (2000) "Strategic brand alliances: Implications of ingredient branding for national and private label brands" Journal of Product \& Brand Management 9(4), 214 228 ,

16. ROBERT L. STEINER, (2004) "The nature and benefits of National Brand/Private Label competition" Review of Industrial Organization 24, 105-127.

17. Scot Burton, Donald R. Lichtenstein, Richard G. Netemeyer Judith A Garretson, (1998) "A scale for measuring attitude toward private label products and an examination of its psychological and behavioural correlates" Journal Of The Academy Of Marketing Science 26 (4), 293-306.

18. Siti Nurafifah Jaafar, Pan Ein Lalp,Mohaini Mohamed (2012) "Consumers' perceptions, attitudes and purchase intention towards private label food products in Malaysia"Asian Journal of Business and Management Sciences 2(8), 73-90.

19. Thomas, J. B., Cassill, N. L., \& Herr, D. G. (1999) "Factors influencing maintained mark-up of national and private apparel brands" Clothing and Textiles Research Journal 17(1), 47-57.

20. Zuraidah Mohamed Isa, Norhidayah Ali, Rabitah Harun, (2011) "Consumers decision making in buying private brand and manufacturer brand" Recent Researches in Social Science, Digital Convergence, Manufacturing and Tourism, 39-43.

\section{AUTHOR PROFILE}

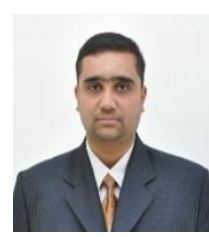

Dr.D.Ganesan is Assistant Professor in Management studies in Sona College of Technology, Salem with 15 + years of experience in Industry and Academia. His doctoral degree in ManonmaniamSundaranar University in effectiveness of advertising messages in audience persuasion. His areas of interest are advertising, consumer psychology and Marketing. He has presented more than 30 papers in various National Conferences .He has published $10+$ articles in various national and International journals. He provided guidance to more than $100 \mathrm{MBA}$ students for project work. He is also interested in organizing business quiz activities for students to prepare and guide them for competitions.

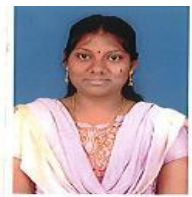

Ms.K.Vidhya MBA,M.COM,(PH.D) doing Full time Research Scholar of Department of Business Administration Under the guideline of DR. S. B. Inayath ahamed at Kalasalingam University. she worked as a " RESEARCH ASSOCIATE" Funded Project (IIPA,DELHI) From the year of 2014 to 2015 at kalsalingam university. She has presented paper national and international conference .she has 10 articles of repute to his credit.she has published three SCOPUS index. She has presented paper IIMK Conference. That paper has published EMERALD Publications. 